\title{
Validation of an agricultural non-point source (AGNPS) pollution model for a catchment in the Jiulong River watershed, China
}

\author{
LIU Jianchang ${ }^{1}$, ZHANG Luoping ${ }^{2, *}$, ZHANG Yuzhen ${ }^{3}$, HONG Huasheng ${ }^{2}$, DENG Hongbing ${ }^{1}$ \\ 1. State Key Laboratory of Urban and Regional Ecology, Research Center for Eco-Environmental Sciences, Chinese Academy of Sciences, Beijing \\ 100085, China.E-mail: amoytiger@163.com \\ 2. State Key Laboratory of Marine Environmental Science, Environmental Science Research Center of Xiamen University, Xiamen 361005, China \\ 3. Fujian Research Academy of Environmental Sciences, Environmental Protection Bureau of Fujian Province, Fuzhou 350003, China
}

Received 15 July 2007; revised 22 August 2007; accepted 29 October 2007

\begin{abstract}
This study tested and evaluated the agricultural non-point source (AGNPS) model for the Wuchuan catchment, a typical agricultural area in the Jiulong River watershed, Fujian Province, China. The AGNPS model was calibrated and validated for the study area with observed data on ten storms. The data on eight storms in 2002 were used for calibration while data on two storms were used for validation of the model. Considering the lack of water quality data over a long-term series, a novel method, comparing an internal nested catchment with its surrounding catchment, was used to supplement the less long-term series data. Dual calibration and validation of the AGNPS model was obtained by this comparison. The results indicate that the correlation coefficients were 0.99 and 0.98 for runoff, 0.94 and 0.95 for the peak runoff rate of the large catchment and the small catchment, respectively, and 0.76 for the sediment of the small catchment only. Each pair of correlation coefficients is homogeneous for the same event for the two catchments. With the exception of the sediment yield and particulate phosphorus, the peak runoff rate and other nutrients were well predicted. Sensitivity analysis showed that the Soil Conservation Service curve number and rainfall quantity were the most sensitive parameters, which resulted in high output variations. Erosivity and other parameters had little influence on the hydrological and quality outputs.
\end{abstract}

Key words: non-point source pollution; agricultural non-point source (AGNPS); agriculture; runoff; nitrogen; phosphorus; sediment

\section{Introduction}

Non-point source (NPS) pollution is an important environmental and water quality management problem. NPS pollution occurs when rainfall, snowmelt, or irrigation water run over land or through the ground, pick up pollutants and deposit them into rivers, lakes, and coastal waters or introduce them into ground water (Arnold et al., 1993). It can be said that the movement of water is like an engine and the use of agricultural land is the fuel (Hassen et al., 2004). The excessive use of commercial inorganic fertilizers for raising crop yields and meeting the demands of population growth in China has resulted in increased nutrient additions and subsequent losses from adjacent coastal catchments (Cao and Zhu, 2000). The increases in nutrient losses and riverine nutrient loads have caused the eutrophication of many coastal and freshwater ecosystems (Nixon et al., 1995; Vitousek et al., 1997; Carpenter et al., 1998). A watershed protection approach is an important strategy to effectively protect a watershed and thereby restore aquatic ecosystems and protect human health (Bhuyan et al., 2003).

Recent studies on the control of agricultural NPS pol-

\footnotetext{
* Corresponding author. E-mail: lpzhang@xmu.edu.cn.
}

lution mainly focus on the simulation models, such as AGNPS (Agricultural Non-point Source Pollution Model) (Young et al., 1987, 1989, 1994), ANSWERS (Areal Non-point Source Watershed Environment Response Simulation) (Beasley et al., 1980), SWAT (Soil and Water Assessment Tool) (Arnold et al., 1993), and BASINS (Better Assessment Science Integrating Point and Non-point Sources) (Whittemore, 1998). Best management practices (BMPs), technical methods to control NPS pollution, are the most typical methods for simulating pollution processes (USEPA, 2000). Several BMPs must be planned and their effectiveness must be tested (Stewart et al., 1975; USNRC, 1993; Correll, 1996).

Watershed modeling can be a valuable tool for studying the relationships between watershed conditions and the quality of water in a watershed. AGNPS is used in this study. It has been applied in numerous watersheds to study the impacts of different landcover scenarios (Koelliker and Humbert, 1989a, 1989b; De Aussen et al., 1998; Mankin et al., 1999). However, none of the studies compared the outputs against measured data of its surrounding catchments or compared with very short-term measured data, because no or few usable stream flow and water quality data were available. Sugiharto et al. (1994) applied the AGNPS model to successfully evaluate 20 management 
practices dealing with the sediment and phosphorus yields from $4 \mathrm{hm}^{2}$ fields in a watershed dominated by dairy farms. The AGNPS model can easily be used to study the effects of changing conditions in a watershed (Lee and White 1992; Tim et al., 1995); the current conditions can also be evaluated and then compared with results from past or future scenarios for the watershed (Mankin et al., 1999). As a very practical tool, it has been proved to be very effective in many regions including southeastern China (Cao et al., 2002; Hassen et al., 2004; León et $a l .$, 2004). This model was also suitable for interfacing with GIS (Geographical Information System) to expedite data input and display/interpret model results (Bhuyan et al., 2003; He, 2003). AGNPS was intended to provide watershed managers with a tool that would enable them to design and target BMPs effective in improving water quality conditions in rural watersheds (León et al., 2004). AnnAGNPS, an annualized AGNPS model, is an update of the single event AGNPS model and can simulate hydrology of a watershed continuously over an annual or long period (Bingner and Theurer, 2001). Although AnnAGNPS has its powerful advantages, the single event AGNPS, which is still selected by many researchers, enables users to process, check, and edit input files, display output files in map format, and execute model simulations through a pull-down menu (He, 2003). The reason for using the model in this study is to obtain dual calculation and validation of agricultural non-point source pollution model by an internal nested catchment comparison, to increase the estimation and/or prediction capability of an eventbased model for water quality assessment of catchments, and to analyze the sensitivity of the model parameters for designing BMPs as the next step to control NPS pollution. Meanwhile, the overall results of this watershed model will aid decision-makers to simulate the pollutant reduction of various BMPs and to create and adopt BMPs within catchments, as well as optimize their action plans for land use regulation and tillage decisions in association with the systems model.

\section{Materials and methods}

\subsection{Site description}

The study area chosen was Wuchuan catchment located in the upstream part of the Jiulong Western River, Fujian Province, southeast China. Based on natural topography boundaries, we divided the Wuchuan catchment into two experimental catchments with areas of 956 and $170 \mathrm{hm}^{2}$, respectively. The large one (the surrounding catchment) is the principal catchment of this study. The small one (catchment B) designed is nested within the large one and located upstream in the same stream. The additional nested catchment $\mathrm{B}$ can promote the precision of debugging the AGNPS model in the principal catchment (catchment A) by a comparison between the measured data of two catchments within the short term.

Rainfall is strongly influenced by the monsoon system. The annual average rainfall is $1,720 \mathrm{~mm}$. Rainfall recorded between July and September (wet season) in 2002 was $1,078 \mathrm{~mm}$, accounting for about $66 \%$ of the total rainfall. The landform is characterized by rolling and undulating hills. The catchment elevation varies between 5.0 and 130 $\mathrm{m}$. The heavily weathered granite base has been dissected by small streams. Agriculture and horticulture are usually developed in the flat alluvial valley. Red earth and lateritic red earth are the main soil types in the whole catchment, with $\mathrm{pH}$ values ranging from 4.0 to 4.8 (mean value, 4.5 ). As a result of increasing the control of soil erosion, the rate of soil erosion has recently decreased to $475 \mathrm{t} /\left(\mathrm{km}^{2} \cdot \mathrm{a}\right)$ (Zhang, 2003). In 2002, the land use in catchment A consisted of forestry, pastures, bamboo, orchards, banana, vegetables, sugarcane fields, paddy fields, fishponds, and residences, with area percentages of $29.9 \%, 5.7 \%, 6.9 \%$, $22.3 \%, 19.2 \%, 1.6 \%, 5.6 \%, 1.8 \%, 2.5 \%$, and $4.5 \%$, respectively, as shown in Fig.1.

By the end of the year 2002, a population of 8,366 with an average income of over 2,500 RMB Yuan per capita in the five villages, one special cultivation farm, and two horticultural companies within catchment A. The catchments are completely agricultural, with no industrial pollution impacts. The dominant economic activity in the area is agronomic farming with a little scattered livestock breeding and multi-pond fisheries. The vegetation, soil, and climate conditions are typical of the Jiulong River watershed. The subtropical weather, beneficial for crop growth, motivates farmers to increase the number of crop rotations in a year as much as possible. The steep terrain

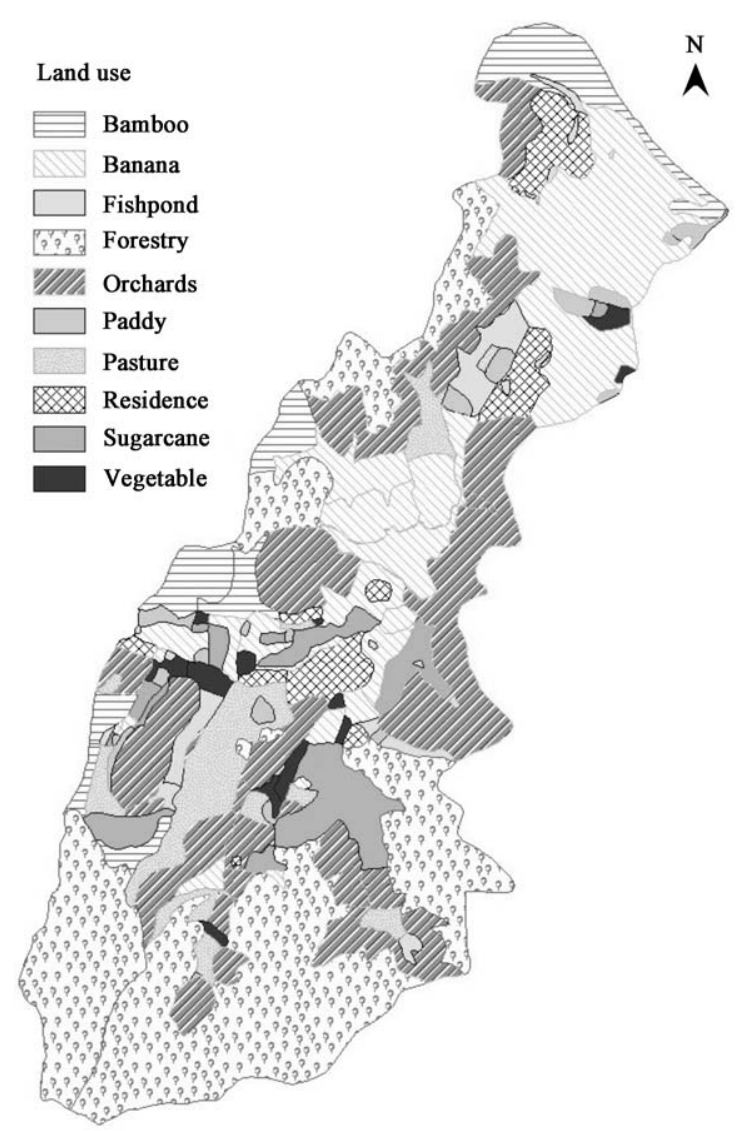

Fig. 1 Land-use in the Wuchuan catchment. 
and erosive soil cause farmers to increasingly overuse fertilizer regardless of the precise nutrient balance in fields required to raise agricultural yields, with the result that nutrients flow into the streams when irrigation is greatly increased or a storm occurs after the application of fertilizer. The amount of chemical fertilizer and manure applied to the agricultural fields in this area far exceeds the demand of crops, and the rate of $\mathrm{N}$ losses resulting from $\mathrm{N}$ overuse is highest in the Jiulong River watershed (Cao and Zhu, 2000). The reasons for choosing the location of the study site can be summarized as follows: its agriculture is very typical of the Chinese subtropics, its land tillage and land uses are very complex, and the severe pollution of coastal waters by the agricultural NPS is of increasing public concern.

\subsection{Parameters of the AGNPS model}

AGNPS 5.0 (version 5.0) is a simulation tool developed by the Minnesota Pollution Control Agency (MPCA), US, Legislative Commission on Minnesota Resources (LCMR), US, Environmental Protection Agency (EPA), US, USDA Soil Conservation Service (SCS), and the USDA-Agricultural Research Service (ARS). It is a computer-based model for estimating the surface water quality in a watershed. The AGNPS model is a single event, distributed-parameter model, which can be used to estimate surface runoff, sediment yield, and nutrient loading from an agricultural watershed. The model accepts inputs from point source pollution, such as feedlots and wastewater treatment plants, and routes these pollutants along with NPS pollutants to estimate overall pollutant loads. The distinctive feature of this model is the discretization of the watershed into small square cells to represent the effects of agricultural management practices on sediment and nutrient loading. Each cell is characterized by 22 input parameters including SCS curve number $(\mathrm{CN})$, terrain description, channel parameters, soil loss equation data, fertilization level, soil texture, channel and point source indicators, and oxygen demand factor. The sediment yield is calculated from a modified form of the Universal Soil Loss Equation (USLE) (Wischmeier and Smith, 1978). The runoff volume is calculated by the SCS curve number method, and the peak runoff rate for each cell is estimated using an empirical relationship proposed by Smith and Williams (1980). The chemical transport of the model estimates the transport of nitrogen and phosphorus throughout the catchment. The relationships used to calculate pollutant levels are taken from the chemicals, runoff, and erosion from Agricultural Management Systems (CREAMS) model developed by Smith and Williams (1980).

Data sources, data collection, and applied methods for the derivation of the input variables and parameters for the AGNPS data sets are shown in Table 1. Primary and secondary data collection methods were used to derive the spatial and attribute data. The first primary data collected were on conservation practices, nutrient use (including chemical fertilizer, livestock manure and drainage from residences), tillage practices, and identification of channel types, with descriptions and determinations of their relative features such as width, depth, and side slope. All this information was collected through a well-developed survey procedure. Field surveys were used to revise the change of vegetation cover based on a former land use map. There were 20 sample sites, as shown in Fig.2, designed for soil section analysis, distributed over both the large catchment

Table 1 Data source, data collection, and applied methods for deriving input variables and parameters for the AGNPS data sets

\begin{tabular}{|c|c|c|}
\hline Input parameter & Method of determination & Data source and collection \\
\hline Cell area & Young et al. (1987) & Objective of study \\
\hline Total number of cells & $\begin{array}{l}277 \text { and } 58 \text { for large and small } \\
\text { catchments respectively }\end{array}$ & Study objective \\
\hline Precipitation & Nanjing Records & Nanjing weather bureau \\
\hline Rainfall erosivity & Smith and Williams (1980) & Najing soil data \\
\hline Cell numbers & Young et al. (1987) & Topographic map \\
\hline SCS curve number & - & Land use, practice, soil data \\
\hline Flow direction & - & Digital Elevation Model (DEM) \\
\hline Flow direction of cell & - & DEM \\
\hline Soil texture & Nanjing Soil Records & $\begin{array}{l}\text { Soil General Survey Bureaux of } \\
\text { Nanjing (1983) and Field Survey }\end{array}$ \\
\hline Slope shape factor & -GIS & DEM \\
\hline Average field slope length & -GIS & DEM and topographic map checking \\
\hline Average land slope & -GIS & DEM and topographic map checking \\
\hline Channel type & - & Field survey \\
\hline Mannings' roughness & Young et al. (1987) & Land use map \\
\hline Average channel slope & - & DEM and relief map checking \\
\hline Average channel side slope & - & Field survey \\
\hline Surface condition constant & Young et al. (1987) & Land use map \\
\hline Soil erodibility factor & Ruan and Zhu (1997) & Local sampling of soil ingredients \\
\hline Cropping factor & Nie (1995), Yang (1999), Cai et al. (2000) & Land use map \\
\hline Practice factor & Nie (1995), David (1992) & References \\
\hline Fertilizer level & - & Field survey \\
\hline Fertilizer availability & Cui (2000) & Tillage practices \\
\hline Channel indicator & - & 1:10000 relief map and digital drainages \\
\hline Impoundment factor & Young et al. (1987) & Field survey \\
\hline Point source indicator & Young et al. (1987) & Field survey \\
\hline
\end{tabular}




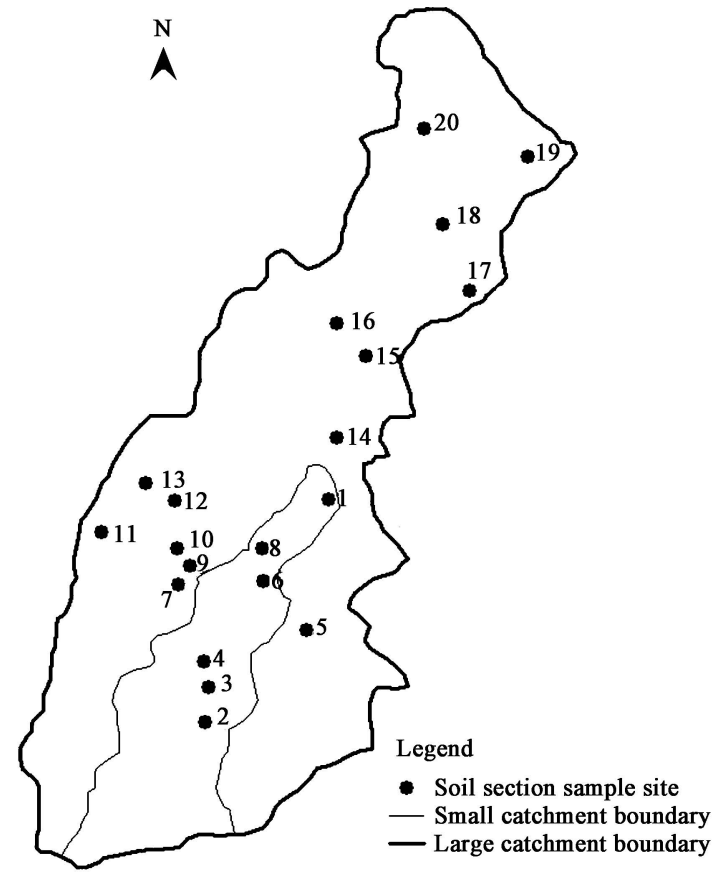

Fig. 2 Sample sites for soil sections in the Wuchuan catchment

and the small catchment.

The database for the research unit includes records of rainfall duration, amount, intensity, and soil erosion for the year 2002. Data on soil loss, runoff, suspended sediment yield, runoff, and runoff rate for the catchment were available from field sampling and monitoring. According to Wischmeier and Smith (1978), an erosive storm is a storm exceeding $12.5 \mathrm{~mm}$ of rain and separated from other rain by more than $6 \mathrm{~h}$, unless as much as $6 \mathrm{~mm}$ of rain falls in $15 \mathrm{~min}$. Ten erosive storms were selected for calibration and validation of the model. The features of these storms are shown in Table 2. Rainfall was measured using an automatic rain gauge and supplementary observation points for daily rainfall. The catchment river runoff and peak flow rate were measured throughout the year using a manual recorder. Catchment sediment loss was monitored from measuring the suspended sediment in the river. After field sampling, total nitrogen (TN), dissolved nitrogen (DN), sediment nitrogen (SN), total phosphorus (TP), dissolved phosphorus (DP), and sediment phosphorus (SP) were measured in the laboratory by colorimetric analyses, and the suspended solid (sediment, SS) was measured by weight loss method after ignition at $105^{\circ} \mathrm{C}$.

The second data collection method involved secondary data used for the SCS-CN, USLE (Wischmeier and Smith, 1978), Stream Power Equation (Bagnold, 1966), and CREAMS (Smith and Williams, 1980), with parameters adapted to the study area. A former research project about the features of agricultural non-point source pollution has built a huge resource database on climate, runoff, land cover, and soil loss at the catchment level since 1999 (Zhang, 2003). This data included meteorological records, river hydrometric measurements, sediment loss, land use, and socio-cultural data. The maps and data so documented provided the basis for testing and evaluating the model. Some of the input parameters were also determined by a geographical information system.

A grid size of $200 \mathrm{~m} \times 200 \mathrm{~m}$ was designed for the partitioning of catchment. This grid size was considered to represent a homogeneous land unit characteristic of the Wuchan catchment. The total numbers of base cells were 277 and 58 cells for the large and small catchments, respectively. The AGNPS initial data and cell parameters were entered for the catchment and each cell, respectively, using the spreadsheet utility to create and edit an AGNPS data file (Young et al., 1989). The model was then run to obtain three outputs: runoff volume, peak runoff rate, and sediment load.

\subsection{Model evaluation and sensitivity analysis}

Calibration and validation were done manually to select values for the parameters so that the model closely simulates runoff, peak runoff rate, sediment yield, and nutrients. Among the initial catchment data required for

Table 2 AGNPS results for calibration and validation

\begin{tabular}{|c|c|c|c|c|c|c|c|}
\hline $\begin{array}{l}\text { Precipitation } \\
\text { event in } 2002\end{array}$ & AMC & $\begin{array}{l}\text { Measured } \\
\text { runoff }\left(\mathrm{m}^{3}\right)\end{array}$ & $\begin{array}{l}\text { Calculated } \\
\text { runoff }\left(\mathrm{m}^{3}\right)\end{array}$ & $\begin{array}{l}\text { Measured peak } \\
\text { flow }\left(\mathrm{m}^{3} / \mathrm{s}\right)\end{array}$ & $\begin{array}{l}\text { Calculated peak } \\
\text { flow }\left(\mathrm{m}^{3} / \mathrm{s}\right)\end{array}$ & $\begin{array}{l}\text { Measured } \\
\text { sediment }^{\mathrm{a}}(\mathrm{t})\end{array}$ & $\begin{array}{l}\text { Calculated } \\
\text { sediment }^{\mathrm{a}}(\mathrm{t})\end{array}$ \\
\hline \multicolumn{8}{|c|}{ Small catchment } \\
\hline 14 May & I & 2,541 & 576 & 0.144 & 0.003 & - & 1.67 \\
\hline 11 June & II & 1,996 & 1,727 & 0.030 & 0.003 & 0.09 & 2.85 \\
\hline 6 July & II & 53,918 & 57,562 & 0.908 & 0.910 & - & - \\
\hline 18 July & III & 14,322 & 10,936 & 0.208 & 0.130 & - & 8.97 \\
\hline 3 August & III & 24,676 & 22,449 & 0.400 & 0.320 & 1.951 & 14.41 \\
\hline 5 August & III & 162,029 & 155,418 & 1.480 & 2.700 & 11.51 & 64.06 \\
\hline 7 August & III & 126,586 & 90,948 & 1.464 & 1.620 & 3.85 & 36.53 \\
\hline 10 August & III & 25,889 & 25,903 & 0.480 & 0.488 & 1.194 & 11.63 \\
\hline 11 September & III & 18,736 & 20,146 & 0.370 & 0.280 & - & - \\
\hline 13 September & III & 56,934 & 63,894 & 0.800 & 1.110 & - & - \\
\hline \multicolumn{8}{|c|}{ Large catchment } \\
\hline 14 May & I & 18,233 & 2,375 & 0.940 & 0.001 & - & 3.00 \\
\hline 18 July & III & 42,786 & 44,544 & 0.460 & 0.513 & - & 5.61 \\
\hline 3 August & III & 112,323 & 133,632 & 1.330 & 1.700 & 15.00 & 35.00 \\
\hline 11 September & III & 126,024 & 133,633 & 1.580 & 1.720 & - & - \\
\hline 13 September & III & 295,289 & 346,455 & 2.530 & 4.200 & - & - \\
\hline
\end{tabular}

a There is no measured or calculated data when annotated with "-". AMC: antecedent soil-moisture condition. I: dry soils but not to the wilting point; II: average moisture condition; III: nearly saturated soils. 
the model, the moisture condition and the storm type for the event must be selected. The run-off curve numbers depend on the soil-water content (moisture condition) and as mentioned above, the curve numbers are one of the parameters that substantially affect the run-off and peak flow rates. The antecedent soil-moisture condition (AMC) represents the watershed soil-moisture content and the runoff curve numbers dependent on the AMC. Options for the model include: dry soils but not the wilting point (type I); average moisture condition (general case for annual floods, type II); and nearly saturated soils (type III) (Table 2).

Sensitivity analysis was conducted for the AGNPS model to guide calibration. Sensitivity analysis is a methodological study of the response to the selected output variables to variations in input parameters and/or driving variables. The 22 AGNPS parameters are not equally important for the model outputs. Ten input parameters that are dynamic in nature were selected for sensitivity analysis: rainfall quantity (RA), energy intensity value (EI), manning coefficient (MA), soil erodibility (K), cropping factor $(\mathrm{C})$, practice factor $(\mathrm{P})$, fertilizer application (Fert), fertilizer available (FA), land shape (LS), slope length (SL), and SCS-CN (CN). Each of the input parameters was varied $\pm 20 \%$ from those of the simulated base values of runoff, peak runoff rate, sediment yield, and nutrients, while the other parameters were kept constant to their standard value. The relative importance of each parameter was evaluated by using the equation set up by Crow et al. (1983).

A simple correlation analysis was made between the measured and predicted data including the test of significance of the correlation coefficients, $r$ (Gomez and Gomez 1984). The accuracy of the model predictions was tested using the efficiency $(R)$ developed by Nash and Sutcliffe (1970). If the observed variable is predicted exactly for all observations, $R$ is 1 . Low values of $R$ represent high deviations between observed and predicted values. If $R$ is negative, predictions are very poor, and an average value for the measured output is a better estimate than the model prediction.

\section{Results and discussion}

\subsection{Calculation and validation of the AGNPS model}

Paired samples (nested catchments samples) correlation coefficients and model efficiency for calibration and validation are presented in Table 3. The results indicated that the calculated values are in line with the monitored data, except for the dissolved phosphorus and sediment in Fig.3.

\subsection{Sensitivity analysis of parameters}

Sensitivity analysis of parameters should be carried out during model simulation. Through sensitivity analysis, the effects of parameters on the model outcome can be obtained by changing their input values. In this study, the precipitation on September 11, 2002 was chosen as a basic rainfall event for further simulation. The precipitation was typical during a year, with a duration of $24 \mathrm{~h}$ and a total rainfall of $50 \mathrm{~mm}$. Two main variables and 11 spatial variables of parameters for sensitivity analysis were selected from a total of 22 variables in the model. The selected parameters can remarkably influence the model simulation. Changes of minus or plus $20 \%$ from the original values were applied to check the responses of the model. A summary of the sensitivity analysis for all the runs performed in this study is presented in Table 4.
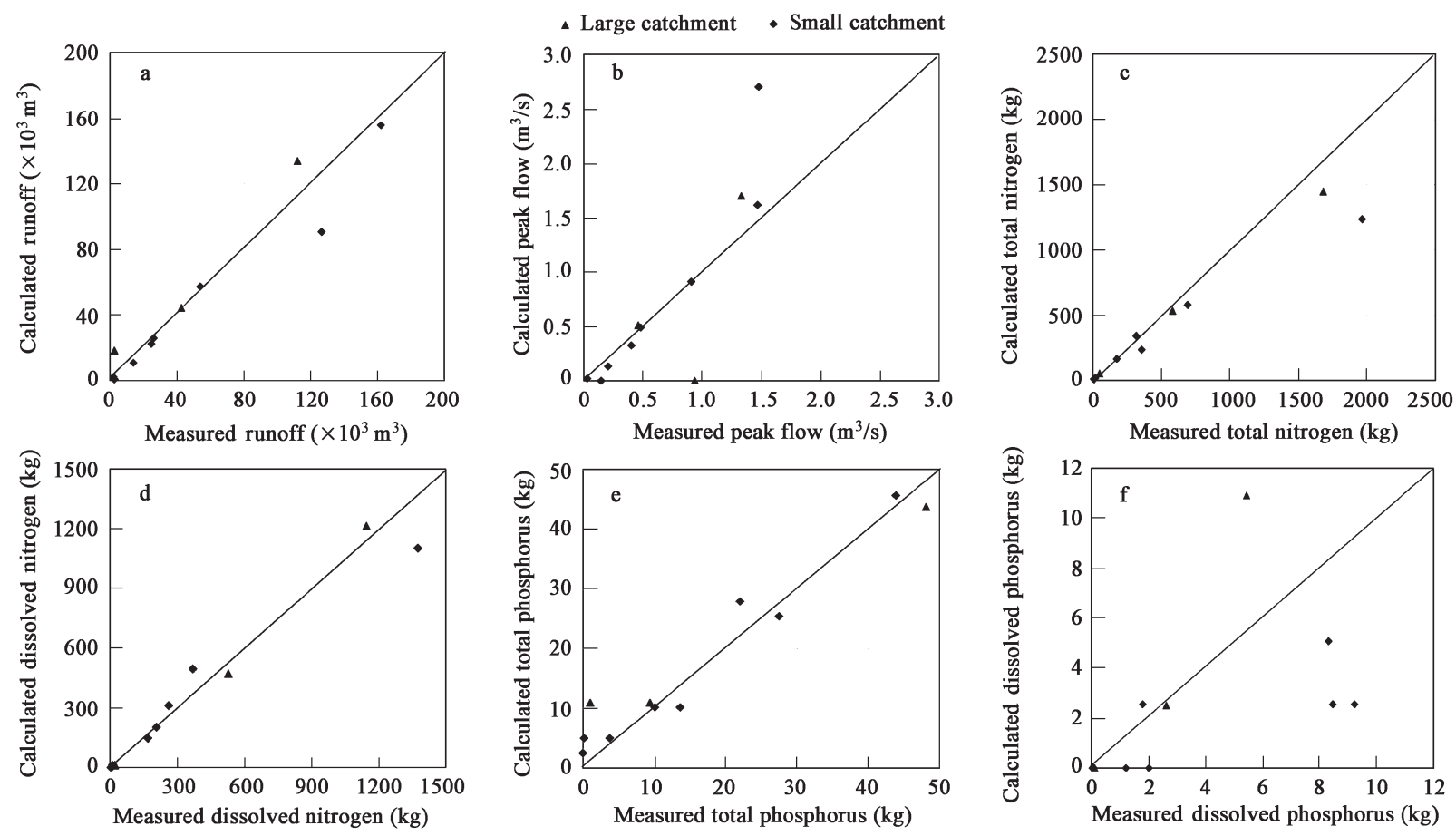

Fig. 3 Measured and calculated runoff (a), peak flows (b), total nitrogen (c), dissolved nitrogen (d), total phosphorus (e), and dissolved phosphorus (f). 
Table 3 Paired samples correlation coefficient $(r)$ and model efficiency $(R)$ for calibration and validation ${ }^{\text {a,b }}$

\begin{tabular}{|c|c|c|c|c|}
\hline \multirow[t]{2}{*}{ Pair } & \multicolumn{2}{|c|}{$r$} & \multicolumn{2}{|c|}{$R$} \\
\hline & Large catchment & Small catchment & Large catchment & Small catchmen \\
\hline Measured against predicted runoff & 0.99 & 0.98 & 0.99 & 0.99 \\
\hline Measured against predicted peak runoff rate & 0.94 & 0.95 & 0.29 & 0.34 \\
\hline Measured against predicted sediment yield & - & 0.76 & - & -1.3 \\
\hline Measured against predicted total nitrogen (TN) & 0.99 & 0.98 & 0.96 & 0.80 \\
\hline Measured against predicted dissolved nitrogen (DN) & 0.99 & 0.98 & 0.99 & 0.93 \\
\hline Measured against predicted total phosphorus (TP) & 0.99 & 0.99 & 0.98 & 0.95 \\
\hline Measured against predicted dissolved phosphorus (DP) & 0.92 & 0.98 & 0.77 & 0.15 \\
\hline
\end{tabular}

a There is not enough measured or calculated data for statistical analysis when annotated with "_". b The values of $r$ and $R$ are integrated values combining the calibration and validation.

Table 4 Summary of sensitivity analysis results of the AGNPS parameters

\begin{tabular}{lll}
\hline Type & Valuation factors & Significant parameters $^{\mathrm{a}}$ \\
\hline Hydrology & Runoff flow & CN, RA \\
& Peak flow & CN, RA, MA \\
Erosion & Suspended solid & RA, CN, EI, MA, K, C, P, LS \\
Nutrient & Particulate nitrogen & CN, RA, EI, K, C, P, LS, MA \\
& Soluble nitrogen & CN, RA, Fert, FA \\
& Total nitrogen & CN, RA, Fert, FA \\
& Particulate phosphorus & EI, CN, RA, MA, SL, \\
& & K, C, P, LS, FA, Fert \\
& Soluble phosphorus & CN, RA, FA, Fert \\
& Total phosphorus & CN, RA, FA, Fert \\
\hline
\end{tabular}

RA: rainfall quantity; EI: energy intensity value; MA: manning coefficient; K: soil erodibility; C: cropping factor; P: practice factor; Fert: fertilizer application; FA: fertilizer available; LS: land shape; SL: slope length; CN: SCS-CN curve number. ${ }^{a}$ Bold capital characters are more significant parameters than the others and the extent of significance is ranked from left to right.

\section{Discussion}

\subsection{Runoff in the calibration of the AGNPS model}

The simple linear correlation coefficient, $r$, for runoff amount was 0.99 for the large catchment and 0.98 for the small catchment, significant at $p \leqslant 0.01$ and homogeneous. This demonstrated that the measured and the predicted runoff were linearly correlated. The model efficiency $(R)$ in both the large catchment and the small catchment was 0.99 . This was a satisfactory result, attributed to the maximum possible calibration (Table 3). The result confirmed the results obtained by Mitchel et al. (1993), Perrone and Madrammooto (1997), and Bhuyan et al. (2003) in Illinois, Quebec, and Kansas watersheds, respectively, that AGNPS simulates runoff with reasonable accuracy. The model prediction for runoff was much better than obtained by Nigussie and Fekadu (2003), Hassen et al. (2004), and Len et al. (2004) in the Augucho catchment, Kori watershed, and a southern Ontario watershed, respectively.

\subsection{Peak runoff rate in the calibration of the AGNPS model}

The correlation coefficient, $r$, between the mean measured and predicted peak runoff rates was 0.94 for the large catchment and 0.95 for the small catchment, significant at $p \leqslant 0.01$ and homogeneous. The coefficient of efficiency was 0.29 and 0.34 in the large and small catchment, respectively. This lower coefficient of efficiency than that in other studies (Hassen et al., 2004; León et al., 2004) indicated good simulation (Nigussie and Fekadu, 2003). The comparison of the maximum value of peak runoff rates indicated a $50 \%$ over-prediction above the observed value. The model over predicted the peak runoff rate particularly for larger rainfall amounts, which is different from the results of Nigussie and Fekadu (2003).

\subsection{Sediment in the calibration of the AGNPS model}

The correlation coefficients were 0.76 for the small catchment, highly significant at $p \leqslant 0.01$. The respective coefficients of efficiency were -1.3 for the small catchment (Table 3). There were not enough data to do a statistical analysis for the large catchment. The high deviation of the model output for sediment yield was also experienced at Salzbode (Central Germany) with a $51 \%$ overestimation (Rode and Frede, 1997). A study conducted in East Central Illinois (USA) on six field-sized watersheds (1.6-30.4 $\mathrm{hm}^{2}$ ) showed that the yield of simulated annual sediment varied from $25 \%$ to $57 \%$ of the observed value (Mitchel et al., 1993). The deviations observed in this study can be explained by the scale of the study and the inconsistencies and random errors in the measurements of the observed data.

\subsection{Nutrients in the calibration of the AGNPS model}

The correlation coefficient, $r$, between the mean measured and predicted TN, DN, TP, and DP was 0.99, 0.99, 0.99 , and 0.92 , for the large catchment; 0.98, 0.98, 0.99, and 0.98 for the small catchment, respectively, significant at $p \leqslant 0.01$ and all homogeneous. The coefficient of efficiency for the TN, DN, TP, and DP was 0.96, 0.99, 0.98 , and 0.77 in the large catchment, and $0.80,0.93$, 0.95 , and 0.15 in the small nested catchment, respectively (Table 3). The good performance of the calibration for nutrients resulted from the high accuracy in calibrating the runoff. The similar results obtained simultaneously in both the large and the small catchment demonstrated that AGNPS was a suitable tool to predict nutrient loss into the environment from the objective catchment.

\subsection{Validation of the AGNPS model}

The comparison of averages in the objective catchment (large one) and the nested catchment (the small one) showed that the simulated values deviated from the observed values by $6.04 \%$ to $17.33 \%$ for runoff, $8.14 \%$ 
to $66.0 \%$ for peak runoff rate, $1.01 \%$ to $6.33 \%$ for total nitrogen, $4.0 \%$ to $25.9 \%$ for dissolved nitrogen, $1.52 \%$ to $6.44 \%$ for total phosphorus, and $4.0 \%$ to $25.9 \%$ for dissolved phosphorus. The coefficients, except for the sediment and peak runoff rate, were in good agreement with the ideal value. All these values indicated that the simulation of the model was highly improved and the validation stage was homogeneous for most events and showed good performance when compared to the calibration stage.

\subsection{Sensitivity analysis of AGNPS model}

The curve number was the most sensitive AGNPS parameter. A respective higher deviation in curve number compared with other AGNPS parameters occured when $\pm 20 \%$ deviation of runoff, peak runoff rate, sediment yield, total nitrogen, dissolved nitrogen, sediment nitrogen, total phosphorus, dissolved phosphorus, and sediment phosphorus, respectively, were input into the model. Next to curve number, changes in rainfall quantity (RA) had the greatest impact on the outputs. Erosivity, slope length, crop cover, erosion factors, conservation practice factors, Manning's roughness coefficient, and the surface condition constant also had some influence on the hydrological and quality outputs. The results of sensitivity analysis of this study were in agreement with the findings in other watersheds on the importance of the $\mathrm{CN}$ parameter (Nigussie and Fekadu, 2003; Hassen et al., 2004; León et al., 2004). The results in both the large and small catchments were shown to be highly homogeneous in the sensitivity analysis.

\section{Conclusions}

Comparison of an internal nested catchment with its surrounding catchment was proved to be an effective pathway to study NPS pollution in the larger catchment by calibrating and validating the watershed model for complex land uses under frequent crop rotations. Researchers can employ the same watershed data twice by this creative comparison. This method virtually extends the amount of observed data. Dual validation and simulation in debugging the AGNPS model was obtained by the comparison of this internal nested catchment. Even if the period of data collection is shorter than usual, the watershed model can still be validated effectively by testing measured data in the surrounding watershed.

The model held true for a subtropical agricultural area in southeast China. The variation of the result (Fig.3) was quite small and increased confidence in the simulation using the AGNPS model. The AGNPS model showed a powerful capability for predicting realistic estimates if the parameter values are assigned correctly. It has been calibrated and validated for a wide range of events, providing realistic estimates of nutrient loads. Typically, the best use for non-point source models is for comparative analysis between different scenarios. This involves modifying parameters to account for the desired change in conditions. The capability to undertake scenarios analysis in defining and managing future land use or BMPs leads to confident evaluation of the changes in watershed hydrology, sedi- ment yield, and nutrient loads caused by modifications of BMPs in land use. The model appears to be well suited to applications in southeastern China and should prove to be a valuable tool in watershed management.

The agricultural NPS pollution data in a watershed is vital for designing management practices using the simulation model. The precision of modeling depends on the quality of the input data. Therefore, uncertainties in the control systems of NPS pollution should be considered in modeling and problem solving. The feasibility of the designed models could be improved if enough uncertain information can be further integrated to reflect the actual agricultural system in the models.

\section{Acknowledgements}

This work was supported by the Key Scientific Project of the Ten-Year Plan of Fujian Province of China (No. 2002H009) and the National Natural Science Foundation of China (No. 70325002). Special thanks go to Prof. Zhao Jing-zhu for his comments on the revision of this paper.

\section{References}

Arnold J G, Allen P M, Bernhardt G A, 1993. Comprehensive surface-ground-water flow model. J Hydrol, 142: 47-69.

Bagnold R A, 1966. An Approach to the Sediment Transport Problem from General Physics, US Geological Survey Professional Paper 422-1. Washington DC: United States Government Printing Office. 1-37.

Beasley D B, Huggins L F, Monke E J, 1980. ANSWERS: a model for watershed planning. Trans Am Soc Agr Eng, 23(4): 938-944.

Bhuyan S J, Koelliker J K, Marzen L J, Harrington J, 2003. An integrated approach for water quality assessment of a Kansas watershed. Environ Modell Softw, 18(5): 473-484.

Bingner R L, Theurer F D, 2001. AnnAGNPS: estimating sediment yield by particle size for sheet and rill erosion. In: Proceedings of the Seventh Interagency Sedimentation Conference, the Sediment: Monitoring, Modeling and Managing. Reno, NV. 25-29 March. Vol. I: 1-7.

Cai C F, Ding S W, Shi Z H, 2000. Study of applying USLE and geographical information system IDRISI to predict soil erosion in small watershed. J Soil Water Conserv, 14(2): 19-24.

Cao W, Hong H, Zhang Y, Ding Y, Yue S, 2002. Testing AGNPS for water quality modeling in agricultural catchment in southeast of China. ACTA Sci Circum, 22(4): 537-540.

Cao W, Zhu H, 2000. Characteristics and Control of Regional Agricultural Ecosystems in Fujian Province. Beijing: China Agriculture Press.

Carpenter S R, Caraco N F, Correl D L, Howarth R W, Sharpley A N, Smith V H, 1998. Non-point pollution of surface waters with phosphorus and nitrogen. Ecol Appl, 8: 559-568.

Correll D L, 1996. Buffer zones and water quality protection: general principles. In: Buffer Zones: Their Processes and Potential in Water Protection (Haycock N. E., Burt T. P., Goulding K. W. T., Pinay G., eds.). Hertfordshire, UK: Quest Environmental. 7-20.

Crow F R, Ghermazien T, Pathak C S, 1983. The effect of land use parameters on runoff simulation by the USDAHL hydrology model. Trans ASAE, 26 (1): 148-152.

Cui Y T, 2000. Fertilizers and Protection of Ecological En- 
vironment. Beijing, China: Chemical Industry Publishing Company.

David R, 1992. Hand Book of Hydrology. New York, USA: McG Raw-Hill Inc.

De Aussen R, Kalita P K, Koelliker J K, Mankin K R, 1998. Application of AGNPS-ARC INFO interface model to an agricultural watershed of Kansas. In: ASAE Paper No. 983139 (St Joseph, eds.). ASAE, MI, USA.

Gomez K A, Gomez A A, 1984. Statistical Procedures for Agricultural Research. International Rice Research Institute, New York, USA. p680.

Hassen M, Fekadu Y, Gate Z, 2004. Validation of agricultural non-point source (AGNPS) pollution model in Kori watershed, South Wollo, Ethiopia. Int J Appl Earth Observ Geoinform, 6(2): 97-109.

He C S, 2003. Integration of geographic information systems and simulation model for watershed management. Environ Modell Softw, 18(8-9): 809-813.

Koelliker J K, Humbert C E, 1989a. Applicability of AGNPS model for water quality planning. In: ASAE Paper No. 892042(St Joseph, eds.). ASAE, MI, USA.

Koelliker J K, Humbert C E, 1989b. Application of AGNPS model to watersheds in northeast Kansas. In: Complete Report of Kansas Soil Conservation Service, Civil Engineering Department, Kansas State University. Manhattan, KS, USA. p167.

Lee M T, White D C, 1992. Application of GIS databases and water quality modeling for agricultural non-point source pollution control. In: Research Report No. 014 of Water Resources Center, University of Illinois at UrbanaChampaigne. Urbana, IL, USA.

León L F, Booty W G, Bowen G S, Lam D C, 2004. Validation of an agricultural non-point source model in a watershed in southern Ontario. Agr Water Manage, 65(1): 59-75.

Mankin K R, Koelliker J K, Kalita P K, 1999. Watershed and lake water quality assessment: An integrated modeling approach. J Am Water Resour Assoc, 35(5): 1069-1080.

Mitchel J K, Engel B A, Srinivasan R, Wang S Y, 1993. Validation of AGNPS for small watersheds using an integrated AGNPS/GIS system. Water Resour Bull AWRA, 29: 833842.

Nash J E, Sutcliffe J V, 1970. River flow forecasting through conceptual models. J Hydrol, 10: 280-292.

Nie B J, 1995. Brief report on C factor and P factor in eroded granitic area in southeast of Fujian Province. Fujian Soil Water Conserv, 4: 43-46.

Nigussie H, Fekadu Y, 2003. Testing and evaluation of the agricultural non-point source pollution model (AGNPS) on Augucho catchment, western Hararghe, Ethiopia Agr Ecosyst Environ, 99(1-3): 201-212.

Nixon S W, Granger S L, Nowicki B L, 1995. An assessment of the annual mass balance of carbon, nitrogen and phosphorus in Narragansett Bay. Biogeochemistry, 35: 15-61.

Perrone J, Madrammooto C A, 1997. Use of AGNPS for watershed modeling in Quebec. Trans ASAE, 40: 1349-1354.

Rode M, Frede H G, 1997. Modification of AGNPS for agricultural land and climate conditions in Central Germany.
J Environ Qual, 26: 165-173.

Ruan F S, Zhu H J, 1997. Soil Erosion and Control over Granite Areas in Fujian Province. Beijing, China: Chinese Agricultural Publish Company.

Smith R E, Williams J R, 1980. Simulation of the surface hydrology. In: CREAMS, A Field Scale Model for Chemicals, Runoff, and Erosion from Agricultural Management Systems, USDA ARS Conservation Research Report 26 (Knisel W., eds.). Washington DC, USA.

Stewart B A, Woolhiser D A, Wischmeier W D, Caro J H, Frere M H, 1975. Control of water pollution from cropland. In: Volume 1, A Manual for Guideline Development, Report Nos. EPA-600/2-75 026a and ARS H-5-1, USEPA/USDA. Washington DC, USA.

Sugiharto T, McIntosh T H, Uhrig R C, Lardinois J J, 1994. Modeling alternatives to reduce dairy farm and watershed NPS pollution. J Environ Qual, 23:18-24.

Tim U S, Jolly R, Liao H S, 1995. Impact of landscape feature and feature placement on agricultural non-point source pollution control. J Water Resour Plan Manage, 121(6): 463-470.

USEPA (US Environmental Protection Agency), 2000. National management measures to control non-point source pollution from agriculture. In: US EPA Contract No. 68-C99-249 Work Assignment. Washington DC, USA. 1-8.

US-NRC (United States National Research Council), 1993. Soil and Water Quality, an Agenda for Agriculture Committee on Long-Range Soil and Water Conservation. Washington DC: National Academy Press.

Vitousek P M, Aber J D, Howarth R W, Likens G E, Matson P A, Schindler D W, Schlesinger W H, Tilman D G, 1997. Human alteration of the global nitrogen cycle: sources and consequences. Ecol Appl, 7: 737-750.

Whittemore R C, 1998. The BASINS model. Water Environ Technol, 10(12): 57-61.

Wischmeier W H, Smith D D, 1978. Predicting Rainfall Erosion Losses, Agriculture Handbook No. 537 of USDA-ARS. Washington DC, USA.

Yang Z S, 1999. The factor of soil and water conservation measures of soil erosion on sloping cultivated land in the northeast mountain region of Yunnan Province. J Mount Sci, 17(Sup): 22-24.

Young R A, Onstad C A, Bosch D D, Anderson W P, 1987. AGNPS: Agricultural non-point source pollution model: a water analysis tool. In: USDA ARS Conservation Research Report. Washington DC, USA. 35-77.

Young R A, Onstad C A, Bosch D D, Anderson W P, 1989. AGNPS: a non-point source pollution model for evaluating agriculture watersheds. J Soil Water Conserv, 44(2): 168173.

Young R A, Onstad C A, Bosch D D, Anderson W P, 1994. AGNPS, Agricultural Non-Point Source Pollution Model, Version 4.03: AGNPS User's Guide. Oxford, Mississippi, USA. July, 1994.

Zhang Y, 2003. Study on Agricultural Non-Point Source Pollution of Wuchuan Catchment in Upstream Jiulong River. Xiamen Unviversity, Xiamen, China. 